\title{
The Clinical Features of COVID-19 Patients with Positive Viral RNA Stool Test Results and Possibility of Fecal-oral Transmission: A Systematic Review
}

\author{
Selina Natalia*, Felicia Imanuella Thorion*, Luky Adlino*, Clifford Eltin John*, \\ Andree Kurniawan **, Nata Pratama Hardjo Lugito** \\ *Faculty of Medicine, Pelita Harapan University, Boulevard Jendral Sudirman street, Karawaci, \\ Tangerang \\ ** Department of Internal Medicine, Faculty of Medicine, Pelita Harapan \\ University, Boulevard Jendral Sudirman street, Karawaci, Tangerang
}

\begin{abstract}
Corresponding author:
Andree Kurniawan. Department of Internal Medicine, Faculty of Medicine, Universitas Pelita Harapan. Jln Boulevard Jendral Sudirman Tangerang Indonesia. Phone: +62-21-54210130; facsimile: +62-21-54210133. E-mail:a125ee@yahoo.com.
\end{abstract}

\begin{abstract}
Background: Coronavirus disease 2019 (COVID-19) has been declared as an international public health emergency by the World Health Organization (WHO). ACE-2 receptors are highly expressed in the upper and lower gastrointestinal system, providing a prerequisite for SARS-CoV-2 infection in the gastrointestinal tract. The aim of this systematic review is to summarize literature and to evaluate the clinical characteristics of patients with positive viral RNA stool test for COVID-19 and if there is a possibility of fecal-oral transmission of SARS-CoV-2 virus.

Method: This systematic review has been registered in PROSPERO (CRD42020183049). A systematic search from PubMed central and Google Scholar through May $5^{\text {th }}$, 2020. Observational and clinical trial were included. Systematic reviews and case reports were excluded. Three reviewers independently searched and selected. The risk of bias was evaluated using Newcastle-Ottawa Quality assessment tool.

Results: 340 articles were screened, then from which eight articles were selected. Diarrhea, nausea, abdominal pain, gastrointestinal bleeding reported as the common symptoms and signs of gastrointestinal involvements. Prolongation of positive stool test results after the respiratory specimen conversion to negative was reported, which support the theory of fecal oral transmission. A positive stool test can be found on COVID-19 patients with any symptoms.

Conclusion: In conclusion, diarrhea, cough, and fever are the most common clinical manifestations in COVID-19 patients with positive RNA stool test results. Fecal oral transmission may be possible due to the ACE2 receptors in the lining of the gastrointestinal tract. RNA stool test should be used as addition in discharging COVID-19 patients.
\end{abstract}

Keywords: COVID-19, Fecal-oral transmission, SARS-CoV-2, viral RNA stool test

\begin{abstract}
ABSTRAK
Latar belakang: Infeksi Coronavirus 2019 (COVID-19) telah ditetapkan sebagai emergensi kesehatan masyarakat oleh organisasi kesehatan dunia WHO. Reseptor ACE-2 banyak terekspresikan di saluran cerna bagian atas dan bawah, yang merupakan syarat virus SARS-CoV-2 masuk ke saluran cerna. Tujuan dari telaah
\end{abstract}


sistematik ini adalah untuk evaluasi karakteristik klinis pasien dengan tes feses RNA positif untuk COVID-19 dan kemungkinan adanya transmisi fekal-oral.

Metode: Telaah sistematik ini telah teregistrasi di PROSPERO(CRD42020183049). Pencarian sistematik dari Pubmed central dan Google Scholar hingga tanggal 5 Mei 2020. Studi observasi dan uji klinik diikutsertakan. Telaah sistematik dan laporan kasus diekslusi. Tiga analist secara mandiri mencari dan memilih. Risiko bias dievaluasi dengan alat ukur Newcastle-Ottawa Quality assessment.

Hasil: 340 artikel tertapis, kemudian akhirnya 8 artikel terpilih. Diare, nausea, nyeri abdomen, perdarahan saluran cerna dilaporkan sebagai gejala dan tanda yang sering untuk keterlibatan saluran cerna. Hasil tes feses positifyang berlanjut setelah konversi ke negative spesimen saluran napas telah dilaporkan. Hal ini mendukung teori transmisi feses-oral. Tes feses positif telah dilaporkan pada pasien dengan gejala apapun.

Simpulan: Diare, batuk dan demam adalah manifestasi klinis yang sering dijumpai pada pasien COVID-19 dengan tes feses RNA positif. Transmisi feses-oral mugkin akibat reseptor ACE-2 yang ada di sepanjang saluran cerna. Tes feses RNA seharusnya digunakan sebagai tambahan untuk kriteria pemulangan pasien COVID-19.

Kata kunci: COVID-19, SARC-CoV-2, test feses viral RNA, transmisi fecal oral

\section{INTRODUCTION}

Coronavirus disease 2019 (COVID-19) has been declared as an international public health emergency by the World Health Organization (WHO), with outbreaks in over 200 countries and causing over 390,000 deaths globally. ${ }^{1-3}$ COVID-19 most commonly known for its respiratory symptoms ${ }^{4}$, but there is evidence that the illness can also present with digestive symptoms such as diarrhea, diminished appetite, and nausea. ${ }^{5,6}$ It has been proven that SARS-CoV-2, the virus that caused COVID-19, uses angiotensin-converting enzyme (ACE) 2 receptor for viral entry. ${ }^{7}$

Meanwhile, ACE-2 receptor is highly expressed in the upper and lower gastrointestinal system, providing a prerequisite for SARS-CoV-2 infection in the gastrointestinal tract. ${ }^{89}$ In addition, over half of the COVID-19 patients have viral nucleic acid detected in their feces ${ }^{10}$ and in almost one-quarter of the cases, the stool samples test positive even when respiratory samples are negative. ${ }^{5,11}$

The aim of this systematic review is to summarize literatures and to evaluate the clinical characteristics of patients with positive viral RNA stool test for COVID-19 and if there is a possibility of fecal-oral transmission of SARS-CoV-2 virus.

\section{METHOD}

This systematic review is registered at PROSPERO (International database of prospectively registered systematic review) with registration number CRD42020183049.

A literature searching was performed on electronic databases, including PubMed Central (https://www. ncbi.nlm.nih.gov/pme/?term=COVID-19+AND+Cli nical+characteristics +AND+Viral+RNA+stool+test + AND+Fecal+oral+transmission) and Google Scholar (https://scholar.google.co.id/scholar?hl=id\&as $\mathrm{sdt}=0 \% 2 \mathrm{C} 5 \& \mathrm{q}=$ COVID $-19+\mathrm{AND}+\mathrm{Clinical}+$ charac teristics + AND + Viral + RNA + stool+test + AND + Feca $1+$ oral+transmission\&btnG $=$ ). A literature searching was conducted on May 5, 2020 using keywords listed in Table 1. Results obtained from the database corresponded to clinical questions using the Boolean system presented in Table 1.

The literature searching process was continued using literature searching limits and relevant titles and abstracts were selected from each database. We searched based on PICO criteria, population, intervention, comparison, and outcome. Studies were included if met following inclusion criteria: $\mathrm{P}=$ COVID-19 patients; I = COVID-19 symptoms and a

Table 1. Literature searching strategy

\begin{tabular}{ll}
\hline Database & Keyword \\
\hline PubMed central & ("COVID-19"[All Fields] OR "COVID-2019"[All Fields] OR "severe acute respiratory syndrome \\
& coronavirus 2"[Supplementary Concept] OR "severe acute respiratory syndrome coronavirus \\
& 2"[All Fields] OR "2019-nCoV"[All Fields] OR "SARS-CoV-2"[All Fields] OR "2019nCoV"[All Fields] \\
& OR (("Wuhan"[All Fields] AND ("coronavirus"[MeSH Terms] OR "coronavirus"[All Fields])) AND \\
& $(2019 / 12[P D A T]$ OR 2020[PDAT])) AND (Clinical[All Fields] AND characteristics[All Fields]) AND \\
& (("rna, viral"[MeSH Terms] OR ("rna"[All Fields] AND "viral"[All Fields]) OR "viral rna"[All Fields] \\
OR ("viral"[All Fields] AND "rna"[All Fields])) AND ("feces"[MeSH Terms] OR "feces"[All Fields] & OR "stool"[All Fields]) AND ("research design"[MeSH Terms] OR ("research"[All Fields] AND \\
& "design"[All Fields]) OR "research design"[All Fields] OR "test"[All Fields])) AND (("feces"[MeSH \\
& Terms] OR "feces"[All Fields] OR "fecal"[All Fields]) AND ("mouth"[MeSH Terms] OR "mouth"[All \\
& Fields] OR "oral"[All Fields]) AND ("transmission"[Subheading] OR "transmission"[All Fields])) \\
& COVID-19 AND Clinical characteristics AND Viral RNA stool test AND Fecal oral transmission. \\
&
\end{tabular}


positive SARS-CoV-2 RNA in stool test; $\mathrm{C}=$ negative SARS-CoV-2 RNA in stool test; $\mathrm{O}=$ COVID-19 characteristics. Observational studies and clinical trials were included. All systematic reviews, commentaries, perspectives, guidelines, case reports, and case series studies were excluded.

Three independent reviewers (CEJ, FIT, and SN) selected the articles, extracted data, and conducted analysis. Any discernment between reviewers was resolved after discussion with the fourth and fifth reviewers (LA and AK). Titles and abstracts for all studies identified through PRISMA search strategy were evaluated by the reviewers. Full texts were evaluated to further determined inclusion and exclusion criteria in chosen text. References in excluded articles were examined to identify studies that may not have been identified through the primary search strategy. Articles were re-evaluated to identify studies that may not been screened through primary strategy. The search was limited to English. A list of potential studies for inclusion in the systematic review was generated through the process.

We reviewed eligible studies and extracted data including details regarding authors, country of study population, demographic data of the patients, clinical characteristics or symptoms present in the study population, and description of outcomes. Data were also extracted data regarding the COVID-19 laboratory results (polymerase chain reaction swabs and viral RNA stool test) and the conclusion of each study about the possibility of fecal-oral transmission.

Multiple article checks were performed on the two databases. The appropriate study was read in full paper and appraised. A critical appraisal was made based on the Newcastle Ottawa for Evidence-Based Medicine which assesses the validity, importance, and applicability of each article. A flow diagram describing the study selection process is shown in Figure 1.

Primary outcomes included the clinical characteristics of COVID-19 patients with positive viral RNA stool test results (using the nucleic acid amplification test (RT-PCR)), and for which the classification variables have been summarized as counts and percentages for each category. Secondary outcomes included the possibility of fecal oral transmission of COVID-19, demographic characteristics of the study population and the duration of stool test result.

The Newcastle-Ottawa Quality assessment of observational trials was used to measure the risk of bias in this systematic review. Two independent researchers (LA and SN) assessed the studies. Methodological quality and the standard of outcome reporting in each

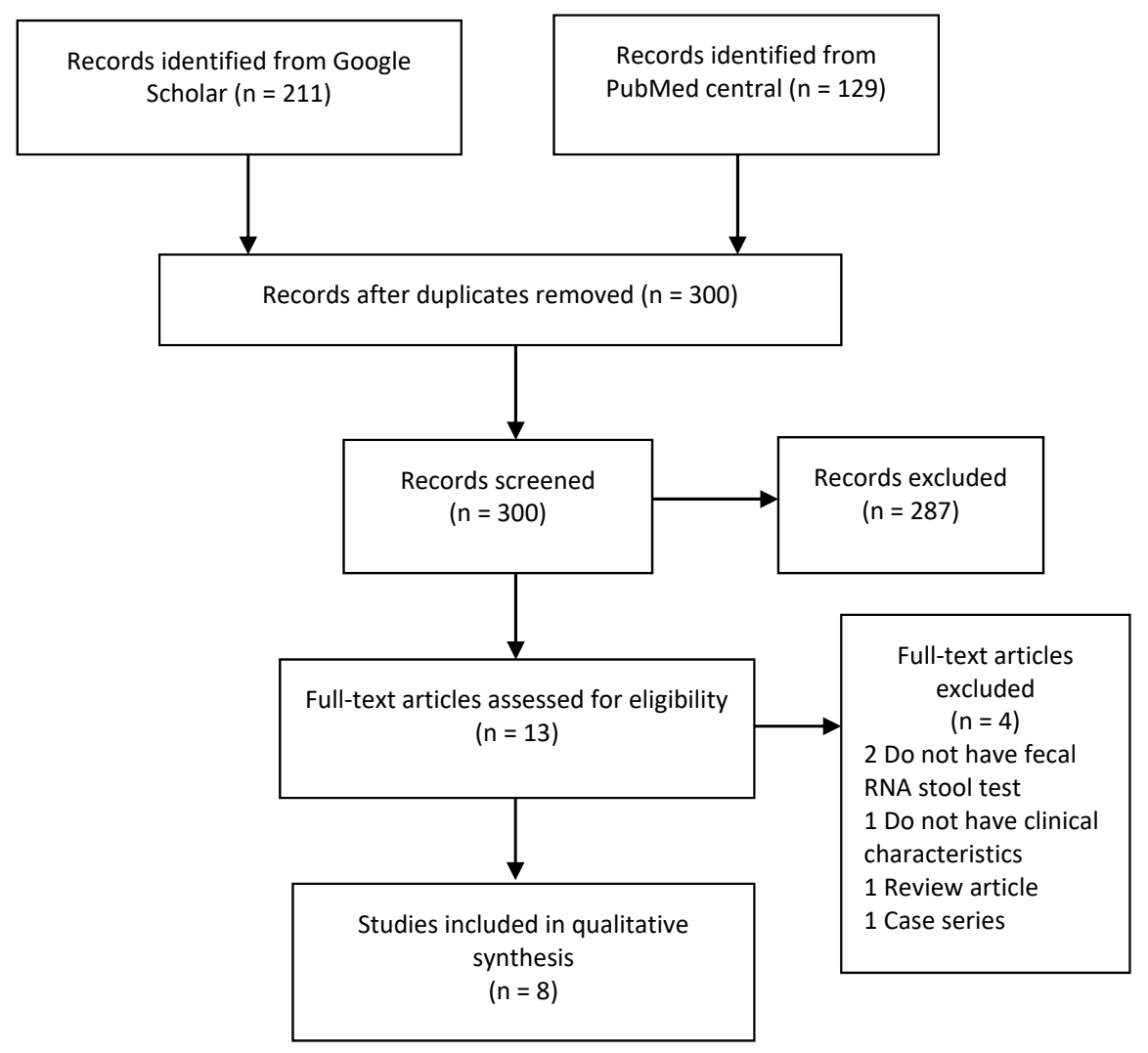

Figure 1. PRISMA diagram of the detailed process of selection of studies for inclusion in the systematic review 
study were assessed thoroughly. Disagreements were solved by consensus and if no consensus existed, the opinions of the third and fourth reviewer (CEJ and FIT) were sought.

\section{RESULTS}

A total of 340 articles were identified through searching strategy. Figure 1 shows the resultant PRISMA diagram (preferred reporting items for systematic reviews and meta-analysis) used. After duplicates were removed, the two primary reviewers (CEJ and FIT) screened titles and abstracts through a total of 300 articles. There were 13 full texts reviewed for eligibility after the initial screen. Most articles were excluded because they did not include information on outcomes selected for our review or not a type of study that we included. Ultimately, eight articles were selected ${ }^{10,12,13-18}$ with a total of 364 patients.

The main characteristics of the eight studies included in the review (study types, clinical characteristics of the patients, results of the viral RNA stool test, study conclusion regarding fecal oral transmission) are summarized in Table 2. Among the eight included studies, five of them had retrospective cohort design, while three of the rest had prospective cohort design. All of the studies that included in this systematic review described the method and condition they used for patient selection. No randomization method was used in these studies. Study populations were confirmed to have the diagnosis of COVID-19 by using RT-PCR from the nasopharyngeal specimen. In one study, only 22 patients, amongst 206 study populations, were tested for viral nucleic acid in their stool. ${ }^{12}$ For the rest of the study, all of the COVID-19 patients were tested for viral nucleic acid in their stool. The comorbidities in the study population were clearly described in three studies, while another did not describe the comorbidities. . $^{10,13,14}$

Authors of the eight studies gave their interpretation and conclusion about the possibility of fecal oral transmission of SARS-CoV-2 virus, yet none of them did any further research about this particular topic. ${ }^{10,12,13-18}$

All eight included studies ${ }^{10,12,13-18}$ involved patients aged 2 months - 92 years old with confirmed positive SARS-CoV-2 infection by RT-PCR from respiratory tract samples either from nasopharyngeal or oropharyngeal swabs. The study by Han et al., only included patients with mild disease severity, defined as symptoms without dyspnea, without clinical evidence of respiratory distress and were able to maintain blood oxygen saturation above $93 \%$ in resting condition. ${ }^{12}$ Meanwhile, the other studies included all patients without restriction regarding the severity of their study population. Study by Xu et al and Xing et al specified their study population to only pediatric patients (Table 2). Beside that, all of the studies had available viral RNA stool test results using RT-PCR from fecal specimen. ${ }^{10,12,13-18}$

From all included studies, we tried to group the clinical characteristics of COVID-19 patients with positive RNA stool test results stated by each study into three general categories. They are digestive symptoms, respiratory symptoms, and other symptoms. Three out of eight studies had a different approach or some limitation in order to follow our method in grouping the clinical characteristics of the study population..$^{10,12,17}$ One study by $\mathrm{Xu}$ et al, did not describe the clinical characteristics of COVID-19 patients with positive stool test result. ${ }^{17}$ Meanwhile, study performed by Han et al, did not mention the specific symptoms the patients had. ${ }^{12}$ The study by Xiao et al. also did not mention each of the respiratory symptoms. ${ }^{10}$

In the digestive category, five studies stated diarrhea as one of the common symptoms. Each study has found a variable number of patients and percentage for the cases of diarrhea, i.e. $21.43-80 \%{ }^{10,13,14,16,18}$ Abdominal pain was found in the study population of three studies, the percentage for each study is $20 \%, 10.71 \%, 33.4 \%$, respectively. ${ }^{13,14,18}$

Other digestive symptoms such as nausea, was stated by two studies as the clinical manifestations of COVID-19 patients. In the study by Lo et al, $50 \%$ of the study's population had this symptom. ${ }^{13}$ Contrary to it, the other study by Chen et al wrote that nausea was only found in $7.14 \%$ from their study population. ${ }^{14}$ Around $10.27 \%$ patients in the study by Xiao et al had gastrointestinal bleeding as one of the SARS-CoV-2 gastrointestinal manifestation. ${ }^{10}$ Meanwhile, vomiting was only found in $3.57 \%$ patients from the study performed by Chen et al. ${ }^{14}$

In the respiratory category, the majority of included studies (five out of eight) stated that cough is a common clinical characteristic. The percentages of cases are $50 \%, 57.14 \%, 50 \%, 80 \%$, and $33.4 \%$ patients in study by Lo et al, Chen et al, Xu et al, Li et al, and Xing et al. respectively. ${ }^{13-16,18}$ Moreover, three studies found sore throat in $50 \%, 25 \%$, and $20 \%$ for study by Lo et al., $\mathrm{Xu}$ et al., and Li et al., respectively. ${ }^{13,15,16}$ Dyspnea was reported in $50 \%$ patients by Lo et al. and $25 \%$ patients by Chen et al. ${ }^{13,14}$ Other respiratory manifestations 


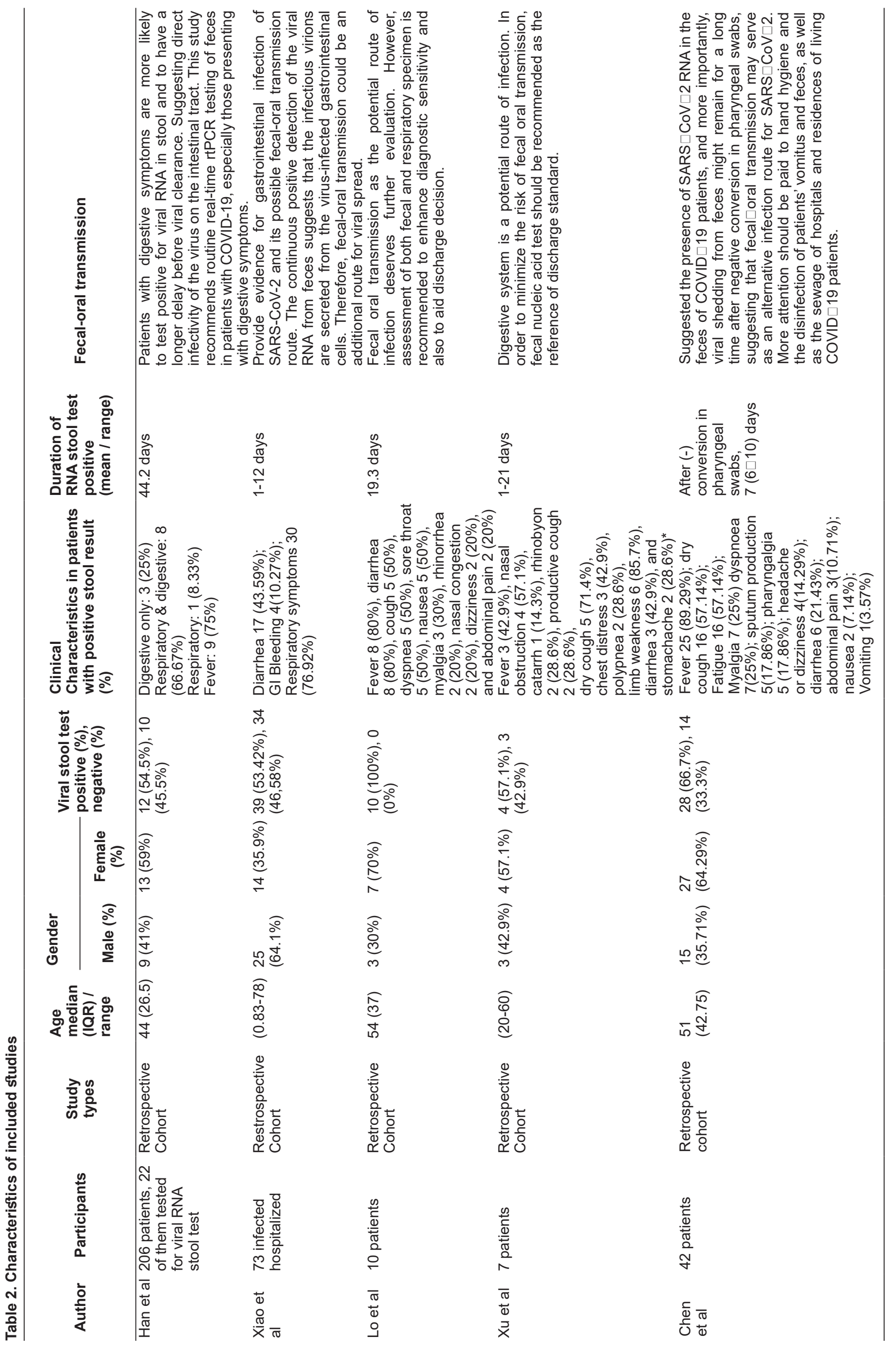




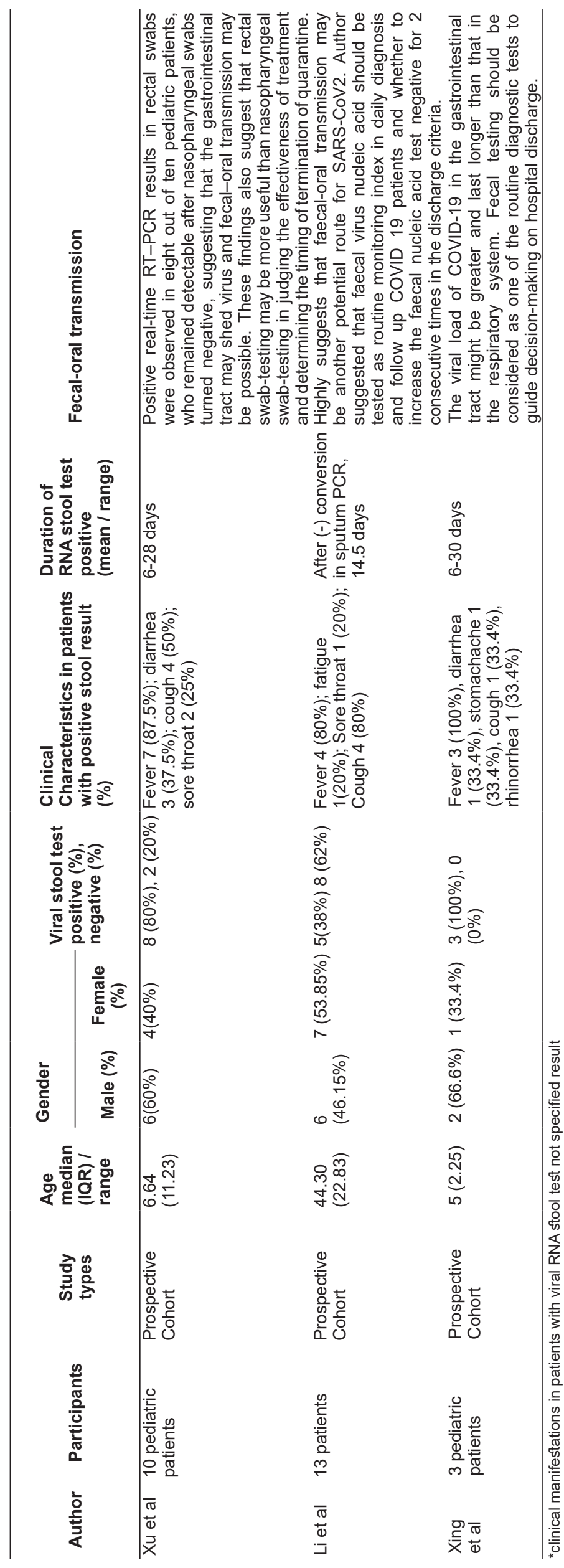


including flu-like symptoms (nasal congestion, rhinorrhea), sputum production and pain in pharyngeal were also reported by some of the studies (Table 2).

For other symptoms that are not classified in the digestive and respiratory category, they will be included into others category. Fever was reported in six studies, each of them point out that, 50 percent or more of their study population, had this symptom, i.e Han et al (75\%), Lo et al (80\%), Chen et al (89.29\%), Xu et al $(87.5 \%)$, Li et al $(80 \%)$, and Xing et al $(100 \%){ }^{12-}$ ${ }^{16,18}$ Study by Chen et al also mention other symptoms such as myalgia, fatigue, dizziness, and etc.(Table 2$)^{14}$

Authors from included studies interpret their findings to give a general representation of fecal oral transmission possibility. All eight studies show prolonged positive RNA stool test results even though nasal swabs were tested negative. Two studies stated that prolonged positive RNA stool test results represent viral shedding in gastrointestinal cells, meaning COVID-19 target receptors were also present in gastrointestinal system. ${ }^{10,12}$ In five of the included studies it is proven that $23.29-80 \%$ of the study population still have SARS-CoV-2 RNA detected in their fecal specimens, even after they were declared cured from COVID-19 (two negative respiratory swab test results in 24 hour span). ${ }^{10,12,14,16,18}$

Furthermore, six out of eight studies stated that it is recommended to do viral RNA stool test before discharging the patients or determining termination of the quarantine. ${ }^{12,13,15-18}$

Studies by Xiao et al and $\mathrm{Xu}$ et al used range in order to describe their study population ages. ${ }^{10,17}$ Meanwhile, the rest of the study used median (IQR) in order to describe their study population. The youngest median age to be included in this study is 2 months old, while the oldest is 78 years old. ${ }^{10,16}$ In four studies male is more affected than female, and in the other four studies, female is the dominant population who are affected. ${ }^{10,12-18}$

Two studies described the duration of prolonged positive stool test results after two times negative respiratory swab test results. ${ }^{14,15}$ Study by Chen et al have stated that a seven (six to ten) days median (IQR) duration time of positive viral RNA in feces. ${ }^{14}$ On the other hand, study by Li et al described the mean duration of viral conversion in two patients was 14.5 days. ${ }^{15}$ Meanwhile, the other four studies described the symptoms duration in the range of one to 30 days from the onset until the resolution. ${ }^{10,16-18}$ The study by Han et al and Lo et al described the duration using the mean, 44.2 days and 19.3 days, respectively. ${ }^{12,13}$

Table 3 summarizes the Newcastle-Ottawa Quality (NOQ) assessment of observational trial results for studies included in the review. Out of eight studies assessed, were rated "good" quality. ${ }^{10,12,13,15,17,18}$ GRADE analysis was not done because this study does not continue to a meta-analysis.

\section{DISCUSSION}

In daily clinical practice, the most common phrase heard worldwide is COVID-19 or known as 2019 Novel Coronavirus. Unlike SARS and MERS, COVID-19 mainly affects the respiratory tract as well as the gastrointestinal system causing diarrhea and abdominal pain. ${ }^{19}$ Even though droplets are the main human-to-human mechanism of transmission of COVID-19, fecal shedding with environmental contamination may also play an important role in viral spread. $^{20}$

In this systematic review, diarrhea shows as the most common gastrointestinal complaint in COVID-19 patients with positive RNA stool test, but not all of the patients have diarrhea, as shown by the percentages. This finding suggested that diarrhea may appear as a common complaint in COVID-19 patients, but not always indicating the presence of viral RNA in the feces. Other gastrointestinal complaints such as abdominal pain, nausea, vomiting, and gastrointestinal bleeding were also found in our study but in a lesser percentage. The gastrointestinal symptoms in positive RNA stool test patients were similar to COVID-19 patients diagnosed by respiratory swab. Observations to date indicate that $2-35 \%$ COVID-19 patients diagnosed by respiratory swab have experienced some gastrointestinal (GI) symptoms, such as diarrhea,

Table 3. Newcastle-Ottawa quality assessment of observational trials

\begin{tabular}{|c|c|c|c|c|c|c|}
\hline First author, year & Study design & Selection & Comparabillity & Exposure/Outcome & Total score & Result \\
\hline Xiao et al 2020 & Cohort & $\star * \star * \star$ & $* *$ & ** & 8 & Good \\
\hline Li et al 2020 & Cohort & $* * *$ & * & $* * *$ & 7 & Good \\
\hline Xu et al 2020 & Cohort & $* * *$ & ** & $* *$ & 7 & Good \\
\hline Chen et al 2020 & Cohort & $* * \star *$ & ** & $\star * *$ & 9 & Good \\
\hline Han et al 2020 & Cohort & $* * * *$ & ** & $* * *$ & 9 & Good \\
\hline Xu et al 2020 & Cohort & $* * *$ & ** & $* * * * * *$ & 8 & Good \\
\hline Lo et al 2020 & Cohort & $* * *$ & * & $* * * * * *$ & 7 & Good \\
\hline Xing et al 2020 & Cohort & $* * *$ & * & $* * * * * *$ & 7 & Good \\
\hline
\end{tabular}


abdominal discomfort, gastrointestinal bleeding, nausea, and vomiting, although these symptoms are much less prevalent than respiratory involvement. ${ }^{21,22}$

Respiratory involvement in patients whose stool tested positive for SARS-CoV-2, was mostly dominated by cough where four studies show above $50 \%$ of their population have cough. Other respiratory symptoms such as dyspnea and sore throat were also commonly complained. Considering that our study subjects are basically COVID-19 patients diagnosed by RT-PCR via the respiratory specimens, we can conclude that the respiratory symptoms may not be related with the stool test results. Besides, we also found that fever was still a major complaint (>75\%) in patients with positive RNA stool tests, as reported in six studies. Moreover, study by Cipriano et al. confirmed that almost all patients had fever as the initial symptoms. ${ }^{23}$ Fever was also the most common symptom in COVID-19 patient with positive RT-PCR in respiratory samples. ${ }^{24}$

Present study has identified the finding of positive stool test duration with or without respiratory SARSCoV-2 test conversion. The Possibility of COVID-19 to be transmitted by fecal oral route may be similar to its predecessor, SARS. According to Li et al. a few years back in China there is evidence of fecal oral transmission for SARS where a community infection occurs from an infected person using their families' toilet. ${ }^{15}$ Another evidence shown from the previous outbreak of SARS, where workers and cleaners in a hospital get infected without direct contact with the patients. ${ }^{25}$ Current findings of stool test positive for SARS-CoV-2 supports the evidence of ACE-2 receptor inside the gastrointestinal system. ${ }^{10} \mathrm{~A}$ study from Xiao et al. using immunohistologic and immunofluorescent staining of gastrointestinal tissues shows that SARSCoV-2 expressed abundantly in the glandular cells of gastric, duodenal, and rectal epithelial, supporting current theory about ACE-2 receptor as cell entry mediator in COVID-19. This might be considered as one of the pathophysiology of positive viral shedding in feces. However, it needs further investigation and evidence to determine fecal oral transmission especially. ${ }^{10}$ Other study also reported that another factor for instance, gut microbiota has been shown to affect the ACE-2. ${ }^{26}$

Regarding the duration of stool test results, in this systematic review there are two studies who described prolonged positive RNA stool test after negative swab results from respiratory specimens. ${ }^{14,15}$ Viral RNA stool samples might still be positive despite a negative respiratory swab result. A study by Cai et al further reported that some patients who had recovered from the illness or had been asymptomatic, still tested positive for viral RNA in their stool..$^{27} \mathrm{~A}$ study by Wu et al. said that on average, the fecal samples remained positive for approximately 11 days longer than respiratory samples. ${ }^{28}$

All eight studies reviewed were graded good, although studies conducted by Lo et al and Xing et al had no population with negative SARS-CoV-2 RNA in their stool as a comparison (Table 3). ${ }^{10,12-18}$ Sample size of all included studies were small, ranging from three to 73 patients with tested viral RNA stool, which is likely attributed to late findings or lack of awareness about the role of viral RNA stool test in COVID-19. The retrospective cohort study by $\mathrm{Xu}$ et al described clinical manifestations in COVID-19 patients without being specified for patient with positive RNA stool test. ${ }^{17}$ Sample groups from all of the eight studies mostly gathered from single centers, each with their own treatment algorithms and protocols.

This systematic review has some limitations. First, as it is only the early stages of a new pandemic, there is only a limited amount of studies that have been completed and can be analyzed for our systematic review. More studies are still underway and must be included for a more complete review in the future. Second, we were unable to perform correlations between the presence of fecal viral RNA with the severity of each symptom because this systematic review is mostly reviewing descriptive studies, which described the findings and phenomenon based only on counts and percentages. Third, the sample size for either exposure or control group were not large enough. Finally, this study does not directly confirm that viral particles found in the stool are infectious and capable of disease transmission. We only gather and provide some evidence to support the possibility of fecal oral transmission, future studies should focus more on reactive viral replication and viral viability to confirm whether COVID-19 is possible to spread via fecal oral route.

Findings of positive stool test benefits in several ways. First, hospitals may put more attention to the disinfection of patients' vomit and feces, as well as the sewage of hospitals and residences of living COVID-19 patients. ${ }^{14}$ Second, studies also found that viral RNA in stool was still positive in children even though nasal swabs have been negative. This may indicate that improving hand hygiene in kindergarten will reduce the chance of fecal oral transmission in communities. ${ }^{10,18}$ Third, stool tests should be used as another way to confirm the duration of self quarantine 
in case a person got infected, improving discharge criteria, and breaking the chain of infection. Study by $\mathrm{Xu}$ et al. stated that rectal swab-testing may be more useful than nasopharyngeal swab-testing in judging the effectiveness of treatment. ${ }^{16}$ Lastly, worker and cleaner should be supplied by adequate protection, to further prevent chances of fecal oral transmission. ${ }^{13}$

\section{CONCLUSION}

In conclusion, diarrhea, cough, and fever are the most common clinical manifestations in COVID-19 patients with positive RNA stool test results. In this case we must emphasize that a positive stool test can be found on COVID-19 patients with any symptoms. Fecal oral transmission may be possible due to ACE2 receptors in the lining of the gastrointestinal tract. Furthermore, the fact that positive result of viral RNA in stool might be prolonged, even after negative RT-PCR conversion from the respiratory specimen, supporting this theory. So, we recommend using a routine RNA stool test as one of the indicators for discharging a COVID-19 patient.

\section{REFERENCES}

1. Li Q, Guan X, Wu P, Wang X, Zhou L, Tong Y, et al. Early transmission dynamics in Wuhan, China, of novel coronavirusinfected pneumonia. N Engl J Med 2020;382:1199-207.

2. Bajema KL, Oster AM, McGovern OL, Lindstrom S, Stenger MR, Anderson TC, et al. Persons evaluated for 2019 novel coronavirus - United States, January 2020. MMWR Morb Mortal Wkly Rep 2020;69:166-70.

3. Chen L, Liu W, Zhang Q. RNA based mNGS approach identifies a novel human coronavirus from two individual pneumonia cases in 2019 Wuhan outbreak. Emerg Microbes Infect 2020;9:313-9.

4. Huang C, Wang Y, Li X, Ren L, Zhao J, Hu Y, et al. Clinical features of patients infected with 2019 novel coronavirus in Wuhan, China. Lancet 2020;395:497-506.

5. Gu J, Han B, Wang J. COVID-19:Gastrointestinal manifestations and potential fecal-oral transmission. Gastroenterology 2020;158:1518-9.

6. Pan L, Mu M, Yang P, Sun Y, Wang R, Yan J, et al. Clinical characteristics of COVID-19 patients with digestive symptoms in Hubei, China: A descriptive, cross-sectional, multicenter study. Am J Gastroenterol March 2020;115:766-73.

7. Zhou P, Yang X, Wang X, Hu B, Zhang L, Zhang W et al. A pneumonia outbreak associated with a new coronavirus of probable bat origin. Nature 2020;579:270-3.

8. Harmer D, Gilbert M, Borman R, Clark K. Quantitative mRNA expression profiling of ACE 2, a novel homologue of angiotensin converting enzyme. FEBS Letters 2002;532:10710.

9. Yan R, Zhang Y, Li Y, Xia L, Zhou Q. Structure of dimeric full-length human ACE2 in complex with B0AT1. Biorxiv 2020;01:1-5.
10. Xiao F, Tang M, Zheng X, Liu Y, Li X, Shan H, et al. Evidence for gastrointestinal infection of SARS-CoV-2. Gastroenterology 2020;158:1831-3.

11. Chen L, Lou J, Bai Y, Wang M. COVID-19 disease with positive fecal and negative pharyngeal and sputum viral tests. Am J Gastroenterol 2020;115:790.

12. Han C, Duan C, Zhang S, Spiegel B, Shi H, Wang W, et al. Digestive symptoms in COVID-19 patients with mild disease severity. Am J Gastroenterol 2020;115:916-23.

13. Lo I, Lio C, Cheong H, Lei C, Cheong T, Zhong X, et al. Evaluation of SARS-CoV-2 RNA shedding in clinical specimens and clinical characteristics of 10 patients with COVID-19 in Macau. International Journal of Biological Sciences 2020;16:1698-707.

14. Chen Y, Chen L, Deng Q, Zhang G, Wu K, Ni L, et al. The presence of SARS-CoV-2 RNA in the feces of COVID-19 patients. J Med Virol 2020;92:833-40.

15. LiY, Hu Y, Yu Y, Zhang X, Li B, Wu J, et al. Positive result of Sars-Cov-2 in faeces and sputum from discharged patient with COVID-19 in Yiwu, China. J Med Virol 2020;92:1938-47.

16. Xu Y, Li X, Zhu B, Liang H, Fang C, Gong Y, et al. Characteristics of pediatric SARS-CoV-2 infection and potential evidence for persistent fecal viral shedding. Nature Medicine 2020;26:502-5.

17. Xu M, Liu X, Su C, Zeng Y, Zhang J, Li X, et al. A Research on the Results of Viral Nucleic Acid Tests and CT Imaging Variation of Patients with COVID-19 Medrxiv 2020;01:1-5.

18. Xing Y, Ni W, Wu Q, Li W, Li G, Wang W, et al. Prolonged viral shedding in feces of pediatric patients with coronavirus disease 2019. Journal of Microbiology, Immunology and Infection 2020;53:473-80.

19. Balla M, Merugu G, Patel M, Koduri N, Gayam V, Adapa S, et al. COVID-19, Modern Pandemic: A Systematic Review From Front-Line Health Care Providers' Perspective. J Clin Med Res 2020;12:215-29.

20. Donà $\mathrm{D}$, Minotti $\mathrm{C}$, Costenaro $\mathrm{P}, \mathrm{Da}$ Dalt L, Giaquinto C. Fecal-oral transmission of sars-cov-2 in children. Pediatr Infect Dis J 2020;39:e133-4.

21. Wang D, Hu B, Hu C, Zhu F, Liu X, Zhang J, et al. Clinical characteristics of 138 hospitalized patients with 2019 Novel Coronavirus-infected pneumonia in Wuhan, China. JAMA 2020;323:1061.

22. Yeo C, Kaushal S, Yeo D. Enteric involvement of coronaviruses: is faecal-oral transmission of SARS-CoV-2 possible?. The Lancet Gastroenterology \& Hepatology 2020;5:335-7.

23. Cipriano M, Ruberti E, Giacalone A. Gastrointestinal infection could be new focus for coronavirus diagnosis. Cureus 2020;12: e7422.

24. Wang R, Pan M, Zhang X, Han M, Fan X, Zhao F, et al. Epidemiological and clinical features of 125 Hospitalized Patients with COVID-19 in Fuyang, Anhui, China. Int J Infect Dis 2020;95:421-8.

25. Ho A, Sung J, Chan-Yeung M. An outbreak of severe acute respiratory syndrome among hospital workers in a community hospital in Hong Kong. Annals Int Med 2003;139:564.

26. Lugito NP, Kurniawan A, Damay V, Chyntya H, Sugianto $\mathrm{N}$. The role of gut microbiota in SARS-CoV-2 infection: Focus on angiotensin-converting enzyme 2. Curr Med Issues 2020;18:26:1-3

27. Jiehao C, Jin X, Daojiong L, Zhi Y, Lei X, Zhenghai Q, et al. A case series of children with 2019 novel coronavirus infection: clinical and epidemiological features. Clin Infect 
Dis 2020;71:1547-51.

28. Wu Y, Guo C, Tang L, Hong Z, Zhou J, Dong X, et al. Prolonged presence of SARS-CoV-2 viral RNA in faecal samples. The Lancet Gastroenterology \& Hepatology 2020;5:434-5. 